\title{
Synthesis, insecticidal activity, and phytotoxicity of novel chiral amides
}

\author{
Alex R Aguiar, ${ }^{a}$ Elson S Alvarenga,${ }^{a^{*}} \odot$ Eliete MP Silva, $^{b}$ Elizeu S Farias ${ }^{b}$ \\ and Marcelo C Picançob
}

\begin{abstract}
BACKGROUND: The lesser grain borer, Rhyzopertha dominica (F.) (Coleoptera: Bostrychidae), is an important pest of stored grains worldwide. Chemical control is the main method used to manage this pest, but the continuous use of insecticides can lead to the selection of resistant $R$. dominica strains. Thus, there is a constant demand for the development of new insecticide molecules. This study describes the synthesis of 14 chiral amides and evaluation of their insecticidal activity against $R$. dominica. Their phytotoxicity to wheat (Triticum sativum) seeds is also evaluated.
\end{abstract}

RESULTS: In the screening assay, compounds $8 \mathrm{i}$ and $8 \mathrm{j}$ caused $100 \%$ and $87 \%$ mortality of $R$. dominica. These values did not differ from the mortality caused by Bifenthrin ${ }^{\circledR}(75 \%)$. Amide 8 i presented similar toxicity $\left(\mathrm{LD}_{50}=27.98 \mu \mathrm{mol} \mathrm{g}^{-1}, \mathrm{Cl}_{95}=25.14-30.71\right)$ and speed of action $\left(\mathrm{LT}_{50}=22 \mathrm{~h}, \mathrm{Cl}_{95}=19.34-24.66\right)$ to amide $8 \mathrm{j}\left(\mathrm{LD}_{50}=29.37 \mu \mathrm{mol} \mathrm{g}^{-1}, \mathrm{Cl}_{95}=27.43-31.09\right.$, and $\mathrm{LT}_{50}=19 \mathrm{~h}$, $\mathrm{Cl}_{95}=17.05-20.95$ ) against the pest. Both amides inhibited less than $44 \%$ of wheat growth.

CONCLUSION: Among the tested amides, only $8 \mathrm{i}$ and $8 \mathrm{j}$ were effective in $\boldsymbol{R}$. dominica control and presented no considerable phytotoxicity towards wheat seeds. Therefore, these amides are promising as insecticides for the management of $R$. dominica. (C) 2018 Society of Chemical Industry

Supporting information may be found in the online version of this article.

Keywords: D-mannitol; insecticide; Rhyzopertha dominica; Triticum sativum

\section{INTRODUCTION}

Cereal grains such as wheat, maize, and rice are widely consumed for their low cost and high nutritional value, being the main source of carbohydrates, proteins, vitamin B, and some minerals. Wheat is the most important source of vegetal protein in human food, with about $13 \%$ protein content. Rice is the most important source of carbohydrates for humans, providing over $20 \%$ of the calories consumed worldwide by humans. Although the production of maize is larger than that of rice or wheat, little of that is used for a source of carbohydrate and protein directly by humans. Sweet corns are composed of $76 \%$ water, $19 \%$ carbohydrates, $3 \%$ protein, and $1 \%$ fat. Maize is also a source of $B$ vitamins, thiamin, niacin, pantothenic acid, and folate. ${ }^{1,2}$ These crops are constantly attacked by insect pests that cause economic losses throughout the world. ${ }^{3}$ Rhyzopertha dominica Fabricius (Coleoptera: Bostrichidae) is the main stored wheat pest. The damage caused by this pest occurs because the larvae and adults feed on the interior of the grain kernel with infestation usually occurring during storage. Attack in the field is rare. ${ }^{4}$

The application of insecticides, specifically active ingredients from the classes of pyrethroids, thiocarbamates, organophosphates, and diamides, is the main method for controlling $R$. dominica. ${ }^{5-7}$ However, the indiscriminate use of these molecules can cause loss of efficacy through the selection of resistant insects to these products. This situation makes the development of new insecticides an important and continuous task. ${ }^{8}$
In the development of insecticides, factors other than the efficacy against pests are evaluated, including their side effects on humans and other non-target organisms, fate in the environment, cost-effectiveness, and phytotoxicity on crops., ${ }^{9,10}$ Studies on pesticide phytotoxicity can be carried out using simple tests in laboratories. These tests usually involve the assessment of germination and root/shoot growth of seeds exposed to the pesticides. ${ }^{11}$

Phytochemicals usually exhibit low environmental persistence and toxicity to mammals, which overcome many of the problems arising from the harmful effects of insecticides in the environment and in food security. ${ }^{12,13}$ For these reasons, natural products have been used as models for the development of synthetic pesticides. Amides found in plants of the genus Piper stand out for their biological activities. ${ }^{14,15}$ The dienamides of propyl, butyl, and isobutyl, which are synthetic analogs of piperine, are reported to be effective insecticides against Diaphania hyalinata (Lepidoptera: Crambidae), a key pest of Cucurbitaceae plants. ${ }^{16}$

To the best of our knowledge, there have been no reports for the preparation of chiral amides analogous to dienamides or

\footnotetext{
* Correspondence to: ES Alvarenga, Department of Chemistry, Universidade Federal de Viçosa, Viçosa, MG 36570-900,Brazil. E-mail: elson@ufv.br

a Department of Chemistry, Universidade Federal de Viçosa, Viçosa, Brazil

b Department of Entomology, Universidade Federal de Viçosa, Viçosa, Brazil
} 


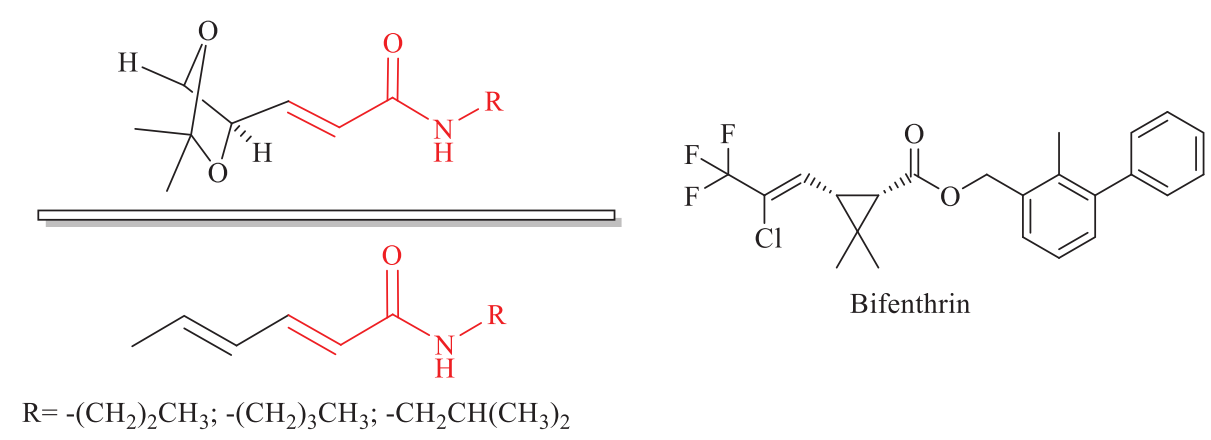

Figure 1. Structural comparison between insecticidal dienamides, chiral amides, and Bifenthrin.

studies correlating the chemical structure with the biological activity of these compounds. These facts were the motivators that led to this research, in which we sought to use dienamides as lead structures for the development of new synthetic insecticides (Fig. 1). It is important to highlight that the efficacy of insecticide molecules may be linked to their stereochemistries. In recent decades, the synthesis of enantiomerically pure compounds has gained prominence mainly in the pharmaceutical and agrochemical industries. ${ }^{17}$ Thus, in this study we describe the synthesis of 14 chiral amides and assess the toxicity of these molecules against R. dominica and their phytotoxicity to wheat (Triticum sativum).

\section{MATERIALS AND METHODS}

\subsection{Chemicals}

\subsubsection{General}

The progress of the reactions was monitored by visualizing the thin layer chromatography (TLC) plates in an ultraviolet (UV) chamber, with a lamp irradiating at $254 \mathrm{~nm} .{ }^{18}$ The melting points were determined on an electrothermal digital apparatus and were not corrected. Infrared spectra were performed on a Fourier transform infrared (FT-IR) Varian 660 equipped with GladiATR (Varian, Palo Alto, CA, USA). Nuclear magnetic resonance (NMR) spectra were recorded on a Varian Mercury $300 \mathrm{MHz}$ spectrometer. Deuterated chloroform was used as solvent and the residual hydrogen of chloroform ( $\delta=7.22 \mathrm{ppm}$ ) was used as reference in the ${ }^{1} \mathrm{H}$ NMR. The signal of the carbon of $\mathrm{CDCl}_{3}$ at $\delta=77 \mathrm{ppm}$ was used as reference in the ${ }^{13} \mathrm{C}$ NMR. Gas chromatography-mass spectrometry (GC-MS) was conducted with a Shimadzu QP5050A gas chromatograph-mass spectrometer (Shimadzu, Japan) using a glass capillary column $(25 \mathrm{~m} \times 0.25 \mathrm{~mm}) \mathrm{DB}-1$. Electron impact $(70 \mathrm{eV})$ was employed to ionize the molecules before fragmentation in the mass spectrometer chamber. The quality (purity) of the compounds was assessed by the ${ }^{1} \mathrm{H}$ and ${ }^{13} \mathrm{C}$ NMR spectroscopy and their identity confirmed by the combined interpretation of NMR, IR, and MS.

\subsubsection{Preparation of ylide}

(carbethoxymethylene)triphenylphosphorane

Ethyl bromoacetate $(20 \mathrm{~g}, 131 \mathrm{mmol})$ was added to a solution of triphenylphosphine $(37 \mathrm{~g}, 141 \mathrm{mmol})$ in dry toluene $(300 \mathrm{~mL})$.
The reaction mixture was heated at $110^{\circ} \mathrm{C}$ for $10 \mathrm{~h}$. The mixture was filtered under vacuum, and the Wittig salt was solubilized in water $(400 \mathrm{~mL})$ and subsequently basified with aqueous sodium hydroxide solution ( $2 \mathrm{~mol} \mathrm{~L}^{-1}, 400 \mathrm{~mL}$ ), forming a yellowish precipitate. The residue was filtered under vacuum to afford the ylide according to Scheme 1.

\subsubsection{Synthesis of 1,2:5,6-di-O-isopropylidene-D-mannitol 2} D-mannitol 1 ( $3.64 \mathrm{~g}, 20 \mathrm{mmol}$ ) was added to a solution of anhydrous zinc chloride $(5.44 \mathrm{~g}, 40 \mathrm{mmol})$ in anhydrous acetone $(100 \mathrm{~mL})$ and the mixture was stirred for $5 \mathrm{~h}$. The reaction mixture was poured onto a suspension of potassium carbonate $(4 \mathrm{~g})$ in water $(4 \mathrm{~mL})$, vigorously stirred, filtered and the zinc carbonate washed with acetone $(50 \mathrm{~mL})$. The filtrate was concentrated and the residue was dissolved in diethyl ether $(20 \mathrm{~mL})$ and transferred to a separating funnel. The organic layer was separated and the aqueous layer was extracted with diethyl ether $(3 \times 10 \mathrm{~mL})$. The diethyl ether was removed under vacuum at room temperature to give a white slurry. Hexane $(50 \mathrm{~mL})$ was added to the slurry and stirred for $20 \mathrm{~min}$. The mixture was kept in the refrigerator for $2 \mathrm{~h}$. The mixture was filtered under vacuum and the solid was dried under vacuum in the desiccator to afford the acetal 2 (4.56 g, 87\% yield). ${ }^{19}$

\subsubsection{Synthesis of 2,3-O-isopropylidene-D-glyceraldehyde 3}

The acetal $2(2.63 \mathrm{~g}, 10 \mathrm{mmol})$ was solubilized in dichloromethane $(50 \mathrm{~mL})$ and, posteriorly, a saturated aqueous solution of sodium carbonate $(1.10 \mathrm{~mL})$ was added. This mixture was kept under stirring in ice bath. Sodium periodate $(4.27 \mathrm{~g}, 20 \mathrm{mmol})$ was added and the mixture was stirred in an ice bath for $2.5 \mathrm{~h}$. Anhydrous magnesium sulfate ( $1.5 \mathrm{~g}$ ) was added and the reaction mixture was filtered. The filtrate was concentrated under vacuum to afford the aldehyde $\mathbf{3}(1.86 \mathrm{~g}, 71 \%){ }^{20}$

\subsubsection{Synthesis of $\mathbf{4 - Z}$ and $\mathbf{5}-\mathbf{E}$}

The aldehyde $3(5.0 \mathrm{~g})$ solubilized in methanol $(100 \mathrm{~mL})$ was added to an ice-cooled solution of the ylide $(10.0 \mathrm{~g}, 30.0 \mathrm{mmol})$. The reaction mixture was stirred for $6 \mathrm{~h}$, the methanol was evaporated and the residue was extracted with hot hexane/diethyl ether (9:1). The residue was purified by flash column chromatography (using
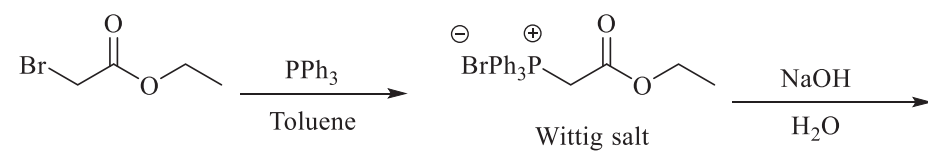

Scheme 1. Synthesis of ylide (carbethoxymethylene)triphenylphosphorane. 


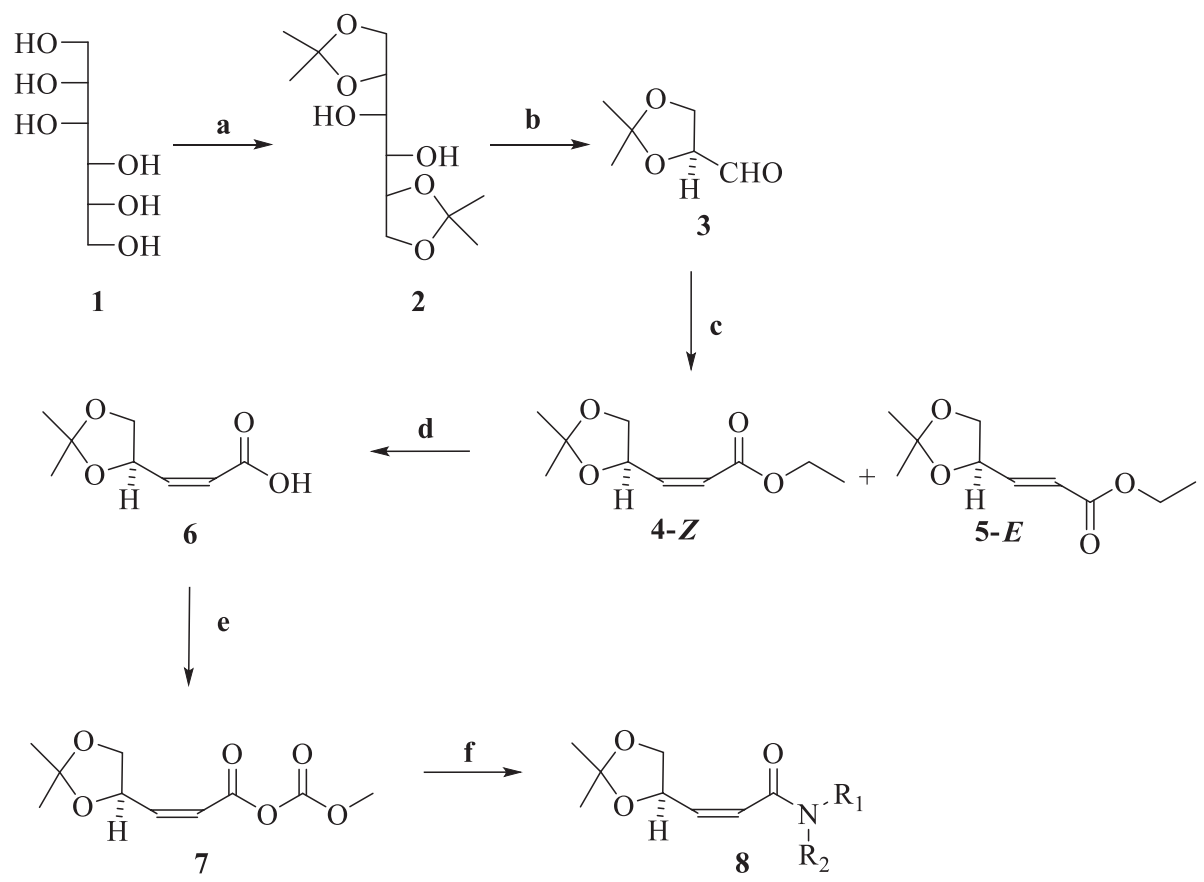

Scheme 2. Reagents and conditions: (a) anhydrous acetone, $\mathrm{ZnCl}_{2}$; (b) $\mathrm{NalO}_{4}, \mathrm{DCM}, \mathrm{Na}_{2} \mathrm{CO}_{3}$; (c) $\mathrm{H}_{3} \mathrm{CCH}_{2} \mathrm{O}_{2} \mathrm{CCHPPh}_{3}, \mathrm{CH}_{3} \mathrm{OH}$; (d) $\mathrm{NaOH}, \mathrm{CH}_{3} \mathrm{OH}$; (e) anhydrous DCM, methyl chloroformate; (f) amine.

a mixture of hexane/ethyl acetate) to give the esters $\mathbf{4 - Z}(3.99 \mathrm{~g}$, $52 \%)$ and 5-E (0.88 g, 11\%).

\subsubsection{Synthesis of the acid 6}

To a solution of the ester $\mathbf{4 - Z}(300 \mathrm{mg}, 1.5 \mathrm{mmol})$ in methanol $(10 \mathrm{~mL})$ was added aqueous sodium hydroxide $(10 \mathrm{~mL}, 4.5 \mathrm{mmol})$ and the mixture was stirred at $25^{\circ} \mathrm{C}$. After $3 \mathrm{~h}$, the mixture was acidified to $\mathrm{pH} 5-6$ with $10 \%$ aqueous citric acid. The methanol was evaporated, the aqueous mixture was diluted with brine $(10 \mathrm{~mL})$ and it was extracted with ethyl acetate $(3 \times 20 \mathrm{~mL})$. The organic phase was separated and the solvent was evaporated at reduced pressure, to give the acid $6(0.26 \mathrm{~g}, 100 \%)$.

\subsubsection{Synthesis of amides $\mathbf{8} \boldsymbol{a}-\mathbf{8} \mathbf{n}$}

The synthetic pathway for compounds $\mathbf{8} \mathbf{a}-\mathbf{8 n}$ is presented in Scheme 2. The acid $6(0.26 \mathrm{~g}, 1.5 \mathrm{mmol})$ was dissolved in DCM $(30 \mathrm{~mL})$, cooled in ice bath, and triethylamine $(0.25 \mathrm{~g}, 1.8 \mathrm{mmol})$ and methyl chloroformate $(0.2 \mathrm{~mL}, 2.1 \mathrm{mmol})$ were added via syringe. The reaction mixture was stirred for $1 \mathrm{~h}$ prior to addition of the corresponding amine. The reaction mixture was stirred for $2 \mathrm{~h}$ and concentrated under vacuum. The residue was purified by flash column chromatography. The amines, eluents, and the reactions yields are presented in Table 1.

\subsection{Bioassays}

Bioassays were conducted with adults of $R$. dominica reared in the laboratory in $1.5 \mathrm{~L}$ glass bottles. To begin this colony, the insects were collected from a maize silo $\left(20^{\circ} 46^{\prime} 13^{\prime \prime} \mathrm{S}, 42^{\circ} 52^{\prime} 22^{\prime \prime} \mathrm{W}\right)$ and reared on whole wheat under constant conditions $\left(28 \pm 2{ }^{\circ} \mathrm{C}\right.$, $70 \pm 5 \%$ relative humidity and $24 \mathrm{~h}$ scotophase). The colony was mass reared for three years (about 21 generations) prior to the bioassays.

Three bioassays were performed with the insect pest. Initially, a screening bioassay was carried out to select the most active amides. Dose-mortality curves for the selected compounds were estimated in the second bioassay. Subsequently, the speed of action was determined for these compounds towards $R$. dominica. All bioassays were performed in a completely randomized design. Each experimental unit consisted of a round plastic container $(6 \mathrm{~cm}$ diameter $\times 5 \mathrm{~cm}$ height, with lid) containing ten insects. Insects were fed with wheat grains $(100 \mathrm{mg})$ added to each container. The compounds were diluted in acetone and topically applied to the abdominal tergum of the insects $\left(0.5 \mu \mathrm{L}_{\text {insect }}{ }^{-1}\right)$ using a syringe (Hamilton model $701 \mathrm{~N}$, Reno, USA). For negative control, the insects were treated with an equal volume of acetone. In order to establish the average mass of the insects, ten adults were weighed on an analytical scale before each bioassay. After the application, insects were kept at the same conditions as in laboratory rearing.

\subsubsection{Screening bioassay}

The treatments were the 14 synthesized amides and the efficiency standard Bifenthrin ${ }^{\circledR}(92.2 \%$ w/w. FMC Quimica, Campinas, Brazil) applied at the dose of $44.05 \mu \mathrm{mol} \mathrm{g}^{-1}$ of insect. ${ }^{21}$ Six replicates were performed for each treatment. Mortality of the insects was evaluated after $48 \mathrm{~h}$. Insects were considered dead when they did not move when prodded with a fine brush. Rhyzopertha dominica mortality data were subjected to analysis of variance and the treatment means were grouped by the Scott-Knott test at the $5 \%$ level using the software $\mathrm{R}^{22,23}$

\subsubsection{Determination of dose-mortality curves of the most active amides against $\mathrm{R}$. dominica}

Dose-mortality curves of the amides $\mathbf{8 i}$ and $\mathbf{8 j}$, and Bifenthrin ${ }^{\circledR}$ (efficiency standard) were estimated. The same procedure described in the screening was used. At least five doses were used for each treatment in order to obtain mortalities ranging from $1 \%$ to $99 \%$. Mortality data were submitted to Probit analysis ${ }^{24}$ to 
Table 1. Amount of the amides $\mathbf{8} \mathbf{a}-\mathbf{8} \mathbf{n}$ obtained in the reaction and their respective yields

\begin{tabular}{|c|c|c|c|}
\hline Amines & Yield (mg;\%) & Eluent & Amides \\
\hline $\mathrm{H}_{2} \mathrm{I}$ & $148 ; 51$ & Hexane/ethyl acetate 1:1 v/v & $8 a$ \\
\hline $\mathrm{H}_{2}$ & $142 ; 48$ & Hexane/ethyl acetate 1:1 v/v & $8 \mathbf{b}$ \\
\hline & $166 ; 56$ & Hexane/ethyl acetate 2:1 v/v & $8 c$ \\
\hline & $178 ; 52$ & Hexane/ethyl acetate 1:1 v/v & 8d \\
\hline & $207 ; 55$ & Hexane/ethyl acetate $1: 1 \mathrm{v} / \mathrm{v}$ & $8 e$ \\
\hline & $123 ; 48$ & Hexane/ethyl acetate 1:1 v/v & $8 f$ \\
\hline & $158 ; 53$ & Hexane/ethyl acetate 1:1 v/v & $8 g$ \\
\hline & $149 ; 49$ & Hexane/ethyl acetate $1: 1 \mathrm{v} / \mathrm{v}$ & $8 \mathrm{~h}$ \\
\hline & $161 ; 50$ & Hexane/ethyl acetate 1:1 v/v & $8 \mathbf{i}$ \\
\hline & $157 ; 45$ & Hexane/ethyl acetate 2:1 v/v & $8 \mathbf{j}$ \\
\hline & $178 ; 50$ & Hexane/ethyl acetate 1:3 v/v & $8 \mathbf{k}$ \\
\hline & $233 ; 66$ & Hexane/ethyl acetate $2: 1 \mathrm{v} / \mathrm{v}$ & 81 \\
\hline & $168 ; 50$ & Hexane/ethyl acetate 1:1 v/v & $8 m$ \\
\hline & $143 ; 44$ & Ethyl acetate/methanol $4: 1 \mathrm{v} / \mathrm{v}$ & $8 n$ \\
\hline
\end{tabular}

estimate the dose-mortality curves and their confidence intervals at the $5 \%$ level $\left(\mathrm{Cl}_{95}\right)$.

\subsubsection{Determination of the survival curves for R. dominica for the most toxic amides}

In order to measure the speed of action of the most active amides, survival curves were estimated. The treatments were the $L D_{90}$ of the selected amides $(\mathbf{8} \mathbf{i}$ and $\mathbf{8 j}$ ) and the negative control (acetone only). Each treatment was set up with $100 R$. dominica adults. The procedures were similar to the previous bioassays. Insect mortality was assessed every 10 min during the first hour of the experiment, followed by $2 \mathrm{~h}$ intervals of observation until the death of approximately $90 \%$ of the insects. Experimental data were submitted to survival analysis using Kaplan-Meier estimators (PROC LIFETEST, SAS 9.2) ${ }^{24}$ to obtain survival curves and estimates of median lethal times ( $\mathrm{LT}_{50}$ values). Overall similarity among the survival curves and $\mathrm{LT}_{50}$ values was tested using the log-rank test, and pairwise comparisons among the curves were tested using the Holm-Sidak test at the $5 \%$ level.

\subsection{Phytotoxicity bioassays}

The phytotoxic effects of the most active amides on wheat seeds were evaluated using five concentrations (500, 400, 300, 200, and $100 \mu \mathrm{mol} \mathrm{L}^{-1}$ ) for each treatment. The wheat seeds (variety BRS-264) used in these experiments were donated by the Department of Crop Science at the Universidade Federal de Viçosa. The compounds were weighed, dissolved in DMSO, and diluted with distilled water to prepare $30 \mathrm{~mL}$ of an aqueous solution containing DMSO $0.3 \% \mathrm{v} / \mathrm{v}$. Half of this solution was used in the bioassays and the other half was diluted with aqueous DMSO $0.3 \%(\mathrm{v} / \mathrm{v})$ to prepare a less concentrated solution. Seeds were treated with $5 \mathrm{~mL}$ of aqueous DMSO $0.3 \%(\mathrm{v} / \mathrm{v})$ for negative control and with the pre-emergence commercial herbicide S-metolachlor (Dual ${ }^{\circledR}$ ) for positive control. Each replicate consisted of 20 seeds kept in Petri 


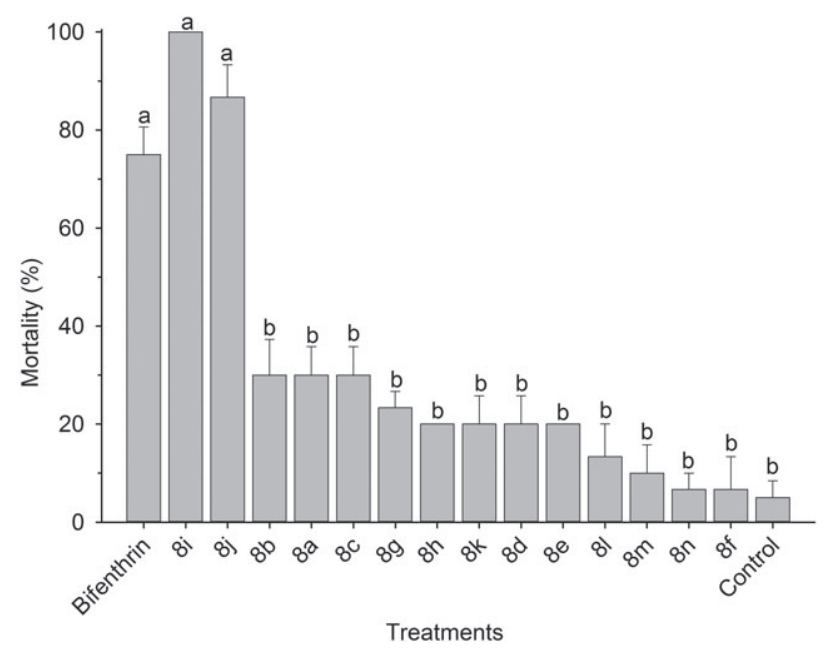

Figure 2. Mortality (mean \pm standard error) of Rhyzopertha dominica adults treated topically with 14 amides and Bifenthrin ${ }^{\circledR}$ (efficiency standard) at the dose of $44.05 \mu \mathrm{mol} \mathrm{g}^{-1}$ of insect. Mortality was assessed after $48 \mathrm{~h}$ of exposure. Means followed by the same letter are in the same group by the Scott-Knott test $(P<0.05)$. Acetone was used as the control.

dishes ( $9 \mathrm{~cm}$ diameter $\times 2 \mathrm{~cm}$ height) containing $5 \mathrm{~mL}$ of test solution. The Petri dishes were sealed with polyvinyl chloride film and stored at $25^{\circ} \mathrm{C}$ and $24 \mathrm{~h}$ scotophase for 5 days. After this period, seeds were digitally photographed and measured for shoot and root length.

Results are presented as percentage inhibition or stimulation, compared to the control. Thus, zero represents the control, positive values represent the stimulation of the parameter and the negative values represent the inhibition.

\section{RESULTS}

\subsection{Synthesis of amides}

The preparation of new chiral amides is depicted in Scheme 2. Promptly available D-mannitol was acetalated using anhydrous acetone and anhydrous zinc chloride to give $\mathbf{2}$ in $87 \%$ yield. Oxidative cleavage of the diacetal $\mathbf{2}$ by sodium periodate led to the 2,3-O-isopropylidine-D-glyceraldehyde $\mathbf{3}$. Wittig reaction of the aldehyde $\mathbf{3}$ with (carbethoxymethylene)triphenylphosphorane gave a mixture of the $\mathbf{4 - Z}$ and $\mathbf{4 - E}$ esters in $63 \%$ yield in a ratio of $4: 1$.

The amide function can be obtained by several synthetic routes. ${ }^{25}$ and each route presents its particularities as yield, reaction time, and reaction condition. The planning of a synthetic route should follow some parameters such as higher yields, reaction time, and reduced number of synthetic steps, besides the selection of reagents that are most efficient.

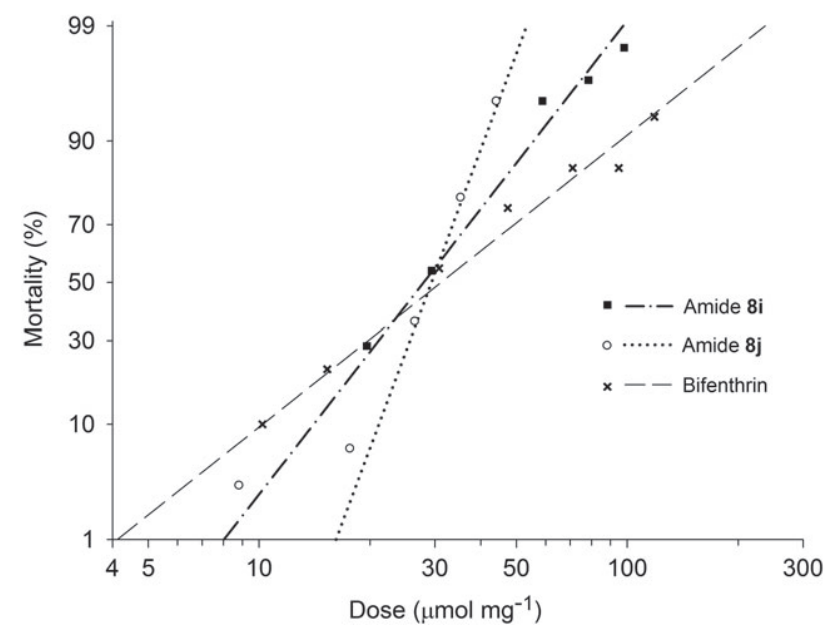

Figure 3. Toxicity of the amides $\mathbf{8 i}, \mathbf{8 j}$, and Bifenthrin ${ }^{\circledR}$ (efficiency standard) against adults of Rhyzopertha dominica $48 \mathrm{~h}$ after application.

First, we attempted to obtain the amides from the direct reaction of the $\mathbf{4 - Z}$ ester with amine, but the Michael addition of the amine to the double bond of $\mathbf{4 - Z}$ was formed as the only product, thus forming amino esters. In a recent study, Barcellos et al. ${ }^{26}$ reported the synthesis of amino esters from the selective addition of amines to the $\mathbf{4 - Z}$ ester. The scope of this reaction was evaluated by the authors through the study of the conjugate addition of a series of primary and secondary amines in different reaction conditions.

From this evidence, the strategy for preparing the amides was to convert the ester to a more reactive functional group. Initially the $\mathbf{4 - Z}$ ester was hydrolyzed, followed by in situ formation of the anhydride. For this purpose, the methyl chloroformate was used in the presence of triethylamine.

It should be mentioned that the methodology chosen for the formation of the amides (via anhydride cleavage) allows the aminolysis of the 4- $\boldsymbol{Z}$ ester more easily, since the anhydride is more reactive than the hydroxyl group. Therefore, the route via the anhydride intermediate favors the preparation of various amides by aminolysis with different amines.

All compounds were purified by silica-gel flash column chromatography and fully characterized by $I R,{ }^{1} \mathrm{H}$ and ${ }^{13} \mathrm{C}$ NMR, and MS (supporting information, Appendix S1). The eluents employed to purify each amide and their corresponding reaction yields are described in Table 1.

\subsection{Toxicity to the insect pest $R$. dominica}

Significant differences in the mortality data of $R$. dominica were observed after $48 \mathrm{~h}$ of exposure to the compounds $\left(F_{15.55}=21.31\right.$,

Table 2. Dose-mortality curves of the most active amides and Bifenthrin ${ }^{\circledR}$ (efficiency standard) for Rhyzopertha dominica adults $48 \mathrm{~h}$ after topical application

\begin{tabular}{lcccrrr} 
Amides & \multicolumn{1}{c}{ Slope $^{\mathrm{a}}$} & $\mathrm{LD}_{50}(\mu \mathrm{mol} \mathrm{g})^{-1}$ & $\left.\mathrm{LD}_{90}(\mu \mathrm{mol} \mathrm{g})^{-1}\right)^{\mathrm{a}}$ & $\chi^{2}$ & $\mathrm{df}$ & 1.26 \\
$\mathbf{8 i}$ & $4.29(3.41-5.17)$ & $27.98(25.14-30.71)$ & $55.68(49.18-66.05)$ & 3 & 0.74 \\
$\mathbf{8 j}$ & $8.97(6.65-11.29)$ & $29.37(27.43-31.09)$ & $40.81(37.96-55.46)$ & 0.22 & 3 \\
Bifenthrin & $2.64(2.19-3.10)$ & $31.24(26.98-35.64)$ & $95.39(80.00-119.90)$ & 3.80 & 5.98 \\
\hline
\end{tabular}

$\mathrm{LD}_{50}$ and $\mathrm{LD}_{90}$, lethal doses to cause $50 \%$ and $90 \%$ mortality; $\chi^{2}$, chi-square test; $\mathrm{df}$, degree of freedom; $P$, probability.

${ }^{a}$ The numbers in parenthesis are the confidence intervals at the $5 \%$ level $\left(\mathrm{Cl}_{95}\right)$. 


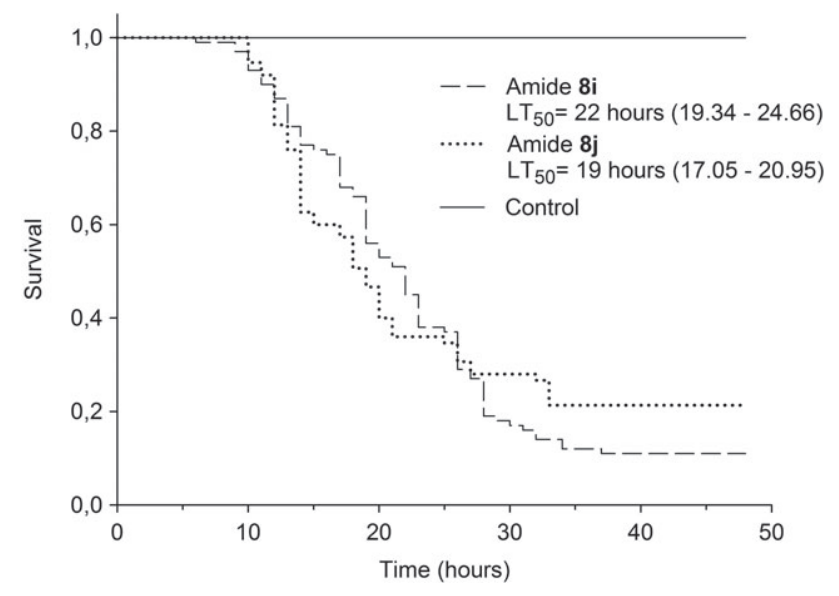

Figure 4. Survival curves and $\mathrm{LT}_{50}$ values (median lethal times) of Rhyzopertha dominica adults treated with the $\mathrm{LD}_{90}$ of the amides $\mathbf{8 i}$ and $\mathbf{8 j}$. The numbers in parenthesis are the confidence intervals of the lethal times at the $5 \%$ level $\left(\mathrm{Cl}_{95}\right)$. Acetone was used as control.

$P<0.001$ ). Compounds $\mathbf{8 i}$ and $\mathbf{8} \mathbf{j}$ were the most efficacious, causing $100 \%$ and $87 \%$ of mortality, respectively. These values did not differ from the mortality caused by Bifenthrin ${ }^{\circledR}(75 \%)$. Mortality of insects submitted to the other treatments ranged from $30 \%$ (amide $\mathbf{8 b}$ ) to 5\% (negative control). Therefore, amides $\mathbf{8 i}$ and $\mathbf{8 j}$ were selected for the subsequent bioassays (Fig. 2).

Amide 8i $\left(\mathrm{LD}_{50}=27.98 \mu \mathrm{mol} \mathrm{g}^{-1}, \mathrm{Cl}_{95}=25.14-30.71\right)$, amide 8j $\left(\mathrm{LD}_{50}=29.37 \mu \mathrm{mol} \mathrm{g}^{-1}, \mathrm{Cl}_{95}=27.43-31.09\right)$, and Bifenthrin ${ }^{\circledR}$ $\left(\mathrm{LD}_{50}=31.24 \mu \mathrm{mol} \mathrm{g}^{-1}, \quad \mathrm{Cl}_{95}=26.98-35.64\right)$ exhibited similar toxicity to the pest as indicated by the overlapping $\mathrm{Cl}_{95}$ values (Table 2). The mortality curve for the amide $\mathbf{8} \mathbf{i}$ had a lower slope (4.29) when compared to the curve for the amide 8j (8.97) (Fig. 3).

There was no significant difference in the survival of $R$. dominica adults treated with the $\mathrm{LD}_{90}$ of compounds $\mathbf{8} \mathbf{i}$ and $\mathbf{8} \mathbf{j}$ (log-rank test, $\left.\chi^{2}=0.19, \mathrm{df}=1, P<0.66\right)$. Median lethal time $\left(\mathrm{LT}_{50}\right.$, lethal time for $50 \%$ of the treated insects) was $22\left(\mathrm{Cl}_{95}=19.34-24.66\right)$ and $19 \mathrm{~h}\left(\mathrm{Cl}_{95}=17.05-20.95\right)$ for insects treated with amides $\mathbf{8 i}$ and $\mathbf{8 j}$, respectively (Fig. 4).

\subsection{Phytotoxicity}

The compounds $\mathbf{8 i}$ and $\mathbf{8 j}$ provided growth stimulus for the shoot at all concentrations (Fig. 5). Growth stimulus ranged from 4\% to $18 \%$ for amide $\mathbf{8 i}$, and $2 \%$ to $6 \%$ for amide $\mathbf{8 j}$. Conversely, S-metolachlor (Dual ${ }^{\circledR}$ ) inhibited above $60 \%$ shoot elongation at all concentrations. Amides $\mathbf{8 i}$ and $\mathbf{8 j}$ inhibited root development at $500 \mu \mathrm{mol} \mathrm{L}^{-1}$ (the highest concentration tested) in $44.3 \%$ and $21.1 \%$, respectively. At lower concentration $\left(200 \mu \mathrm{mol} \mathrm{L}^{-1}\right)$, inhibition of root growth was less than $13 \%$ for amides $\mathbf{8 i}$ and $\mathbf{8 j}$. These values were marginal compared to $S$-metolachlor, which inhibited $70 \%$ root elongation at all concentrations.

\section{DISCUSSION}

Compounds $\mathbf{8} \mathbf{i}$ and $\mathbf{8 j}$ caused more than $80 \%$ mortality to $R$. dominica, a minimum value recommended by Brazilian legislation to select potential insecticide molecules, ${ }^{27}$ indicating that these compounds have the potential to be used as models for future development of agrochemicals for controlling this pest.

The results obtained from this study indicate that the amides $\mathbf{8 i}$ and $\mathbf{8 j}$ present similar toxicity to Bifenthrin ${ }^{\circledR}$, one of the most used protectant insecticides in the management of stored grain pests. ${ }^{28}$ The dose-mortality curve estimated for amide $\mathbf{8 j}$ had a higher slope (8.97) than that for compound $\mathbf{8 i}$ (4.29), indicating a more homogeneous response to $R$. dominica populations exposed to compound $\mathbf{8 i} .^{29}$ Therefore, small variations in doses of compound $\mathbf{8 j}$ can promote broad variations in pest mortality, increasing the risk of failures in $R$. dominica control. ${ }^{30,31}$

In warehouses, high temperatures and moisture contents of grains favor the development of pest insects. ${ }^{32}$ Rhyzopertha dominica, besides consuming grain kernels, deposit feces and cause localized increases in heat and moisture, leading to accelerated mold growth. ${ }^{33}$ Another problem concerning $R$. dominica attack is fragments, such as larval head capsules and adult exoskeletons, left in flour. In several countries, the tolerance of insect residues in stored grain is very low. ${ }^{34}$ In view of this, even low infestations of stored grains are sufficient to decrease the product market value because of customer complaints or lawsuits, resulting in a very low economic threshold for grain products in warehouses. ${ }^{35-37}$ Rhyzopertha dominica females may lay up to 17 eggs per day under high temperatures $\left(32^{\circ} \mathrm{C}\right) .{ }^{38}$ Due to this high reproductive potential, it is desirable for the insecticide to show rapid action on the pest, avoiding the growth of the insect population and new sources of grain contamination. Here, amides $\mathbf{8 i}$ and $\mathbf{8 j}$ promoted efficient control in less than $48 \mathrm{~h}$. These results reinforce the insecticidal potential of amides $\mathbf{8 i}$ and $\mathbf{8 j}$ in the management of $R$. dominica.

Wheat seeds can be stored for sowing purposes and in these situations $R$. dominica can damage the seeds, affecting their viability and vigor. ${ }^{39,40}$ Thus, it is highly desirable that insecticides used in this pest management do not compromise seed quality. Phytotoxic studies of insecticides on wheat seeds are scarce. A study

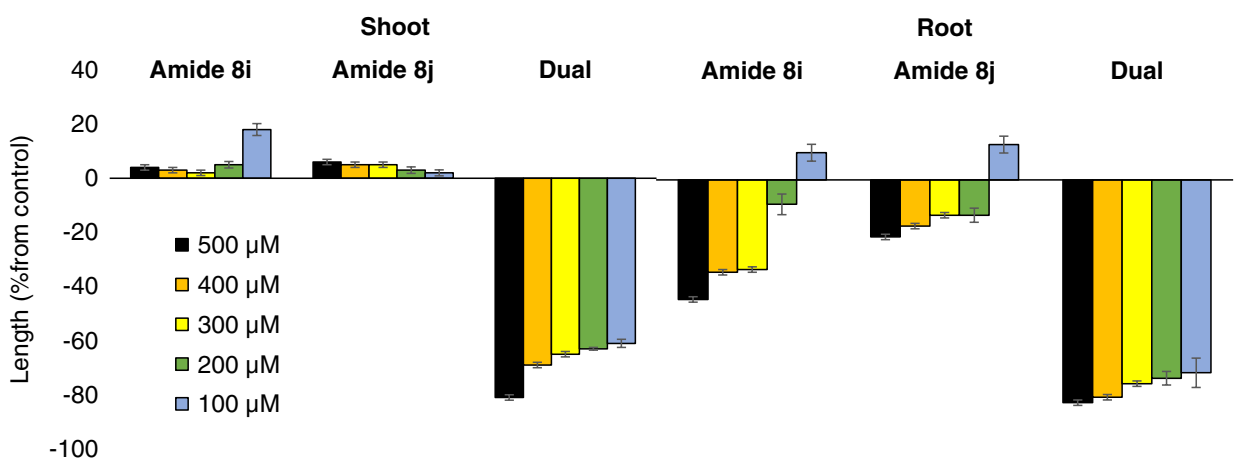

Figure 5. Growth effects (mean \pm standard deviation) of compounds $\mathbf{8 i}$ and $\mathbf{8} \mathbf{j}$ on Triticum sativum. Values are expressed as percentage difference from control. Dual, S-metolachlor. 
performed with the organophosphate malathion did not find adverse effects of this insecticide on wheat germination. ${ }^{41}$ In the present study, amides $\mathbf{8 i}$ and $\mathbf{8} \mathbf{j}$ provided stimulatory effects for shoot elongation at all concentrations. The lowest concentration of these compounds $\left(100 \mu \mathrm{mol} \mathrm{L}^{-1}\right)$ stimulated root elongation but higher doses inhibited it, albeit marginally when compared to the herbicide $S$-metolachlor. Elongation tests with the insecticides Chlorpyrifos, $\alpha$-cypermethrin and $\lambda$-cyhalothrin in onion and tomato presented a similar pattern (growth stimulation at lower concentrations and inhibition at higher). ${ }^{42,43}$ Higher adverse effects of insecticidal molecules on root growth compared to shoot elongation, as observed in this study, have been reported for cypermethrin elsewhere. ${ }^{44}$

\section{CONCLUSION}

Amides $\mathbf{8 i}$ and $\mathbf{8 j}$ present high toxicity and fast action against $R$. dominica. These compounds also exhibit low phytotoxicity to wheat seeds, which is an important attribute when considering potential pesticides. These results indicate that these compounds are promising molecules for $R$. dominica control.

\section{ACKNOWLEDGEMENTS}

We would like to thank the Brazilian agencies FAPEMIG, CNPq, RQ-MG (Rede Mineira de Química), and CAPES for their financial support.

\section{SUPPORTING INFORMATION}

Supporting information may be found in the online version of this article.

\section{REFERENCES}

1 Jood S, Kapoor AC and Singh R, Effect of insect infestation on the organoleptic characteristics of stored cereals. Postharvest Biol Technol 2:341-348 (1993).

2 Arthur FH, Ondier GO and Siebenmorgen TJ, Impact of Rhyzopertha dominica (F.) on quality parameters of milled rice. J Stored Prod Res 48:137-142 (2012).

3 Moreira MD, Picanço MC, Barbosa LCDA, Guedes RNC, de Campos MR, Silva GA et al., Plant compounds insecticide activity against Coleoptera pests of stored products. Pesqui Agropecu Bras 42:909-915 (2007).

4 Padilha $L$ and Faroni LRD, Importância e formas de controle de Rhizopertha dominica (F.) em grãos armazenados, in Simpósio de Proteção de grãos armazenados EMBRAPA-CNPT, Passo Fundo, RS, Brazil, pp. 52-58 (1993).

5 Boyer $\mathrm{S}$, Zhang $\mathrm{H}$ and Lempérière $\mathrm{G}, \mathrm{A}$ review of control methods and resistance mechanisms in stored-product insects. Bull Entomol Res 102:213-229 (2012).

6 Silvério FO, de Alvarenga ES, Moreno SC and Picanço MC, Synthesis and insecticidal activity of new pyrethroids. Pest Manag Sci 65:900-905 (2009).

7 Campos MR, Silva TB, Silva WM, Silva JE and Siqueira HA, Susceptibility of Tuta absoluta (Lepidoptera: Gelechiidae) Brazilian populations to ryanodine receptor modulators. Pest Manag Sci 71:537-544 (2015).

8 Alvarenga ES, Picanço M C, Aguiar RA, Lopes MC, Formulação e uso de amidas derivadas do ácido sórbico com atividade inseticida.Pat. BR 10 2014025903 (2014).

9 Tavares WS, Cruz I, Petacci F, Freitas SS, Serrão JE and Zanuncio JC, Insecticide activity of piperine: toxicity to eggs of Spodoptera frugiperda (Lepidoptera: Noctuidae) and Diatraea saccharalis (Lepidoptera: Pyralidae) and phytotoxicity on several vegetables. J Med Plants Res 5:5301-5306 (2011).

10 Walker $\mathrm{CH}$, Sibly RM, Hopkin SP and Peakall DB, Principles of Ecotoxicology, 3rd edn. CRC Press, Taylor \& Francis Group, 6000 Broken Sound Parkway NW, suite 300 Boca Raton, FL 33487-2742, USA (2006).
11 Moraes FC, Alvarenga ES, Amorim KB, Demuner AJ and Pereira-Flores $\mathrm{ME}$, Novel platensimycin derivatives with herbicidal activity. Pest Manag Sci 72:580-584 (2016).

12 Dayan FE, Cantrell CL and Duke SO, Natural products in crop protection. Bioorg Med Chem 17:4022-4034 (2009).

13 Copping LG and Duke SO, Natural products that have been used commercially as crop protection agents. Pest Manag Sci 63:524-554 (2007).

14 Parmar VS, Jain SC, Bisht KS, Jain R, Taneja P, Jha A et al., Phytochemistry of the genus Piper. Phytochemistry 46:597-673 (1997).

15 Marques JV, Kitamura ROS, Lago JHG, Young MCM, Guimarães EF and Kato MJ, Antifungal amides from Piper scutifolium and Piper hoffmanseggianum. J Nat Prod 70:2036-2039 (2007).

16 Aguiar AR, Alvarenga ES, Lopes MC, Dos Santos IB, Galdino TV and Picanço MC, Active insecticides for Diaphania hyalinata selective for the natural enemy Solenopsis saevissima. J Environ Sci Health Part B 51:579-588 (2016).

$17 \mathrm{Yu} \mathrm{H}$, Yong X, Liang J, Deng J and Wu Y, Materials established for enantioselective release of chiral compounds. Ind Eng Chem Res 55:6037-6048 (2016).

18 Alvarenga ES, Saliba WA and Milagres BG, Montagem de câmara com lâmpada de ultravioleta de baixo custo. Quim Nova 28:927-928 (2005).

19 Alvarenga ES, Teixeira Carneiro VM, Oliveira Silvério F and Argolo Saliba W, A high yield synthesis of 1,2:5,6-di-O-isopropylideneD-mannitol. J Chil Chem Soc 51:986-988 (2006).

20 Mann J, Partlett NK and Thomas A, A practical synthesis of (S)-5-hydroxymethylfuran-2(5H)-one from 1,2:5,6-di-O-isopro pylidene-D-mannose. J Chem Res 11:369 (1987).

21 Daglish GJ, Wallbank BE and Nayak MK, Synergized bifenthrin plus chlorpyrifos-methyl for control of beetles and psocids in sorghum in Australia. J Econ Entomol 96:525-532 (2003).

22 Jelihovschi E, Faria JC and Allaman IB, ScottKnott: a package for performing the Scott-Knott clustering algorithm in R. TEMA (São Carlos) 15:003 (2014).

$23 \mathrm{R}$ Team, R development Core team. RA Lang Environ Stat Comput 55:275-286 (2013).

24 SAS Institute Inc, SAS/STAT 9.2 User's Guide. SAS Institure Inc, Cary, NC (2008).

25 Wu J, Wu Y, Dai J and Xu H, Benzoic acid-catalyzed transamidation reactions of carboxamides, phthalimide. Adv Synth Catal 356:2429-2436 (2014).

26 Barcellos JCF, Vilela GVM d A, BHF B, MFF M, Dias AG and PRR C, The syn-selective conjugate addition of amines to enoates derived from D-mannitol. Tetrahedron: Asymmetry 27:773-776 (2016).

27 Manual de Prodimentos para Registro de Agrotóxicos. Coordenação Geral de Agrotóxicos e Afins, ed. by Ministério da Agricultura Pecuária e Abastecimento pp. 68, (2012). http://www.agricultura .gov.br/assuntos/insumos-agropecuarios/insumos-agricolas/ agrotoxicos/arquivos/manual-de-procedimentos-para-registrode-agrotoxicos.pdf.

28 Pražić Golić M, Andrić G and Kljajić P, Combined effects of contact insecticides and $50^{\circ} \mathrm{C}$ temperature on Sitophilus oryzae (L.) (Coleoptera: Curculionidae) in wheat grain. J Stored Prod Res 69:245-251 (2016).

29 Brown CC, The statistical analysis of dose-effect relationships, in Principles of Ecotoxicology, ed. by Butler G. John Wiley \& Sons, Ltd, Chichester, pp. 115-148 (1978).

30 Resende GC, Alvarenga ES, de Araújo TA, Campos JN and Pincanço MC, Toxicity to Diaphania hyalinata, selectivity to non-target species and phytotoxicity of furanones and phthalide analogues. Pest Manag Sci 72:1772-1777 (2016).

31 Mairink SZ, Barbosa LCA, Varejão EVV, Farias ES, Santos MLM and Picanço MC, Larvicidal activity of synthetic tropane alkaloids against Ascia monuste orseis (Lepidoptera: Pieridae). Pest Manag Sci 73:2048-2053 (2017).

32 Flinn PW, Hagstrum DW, Reed CR and Phillips TW, Stored Grain Advisor Pro: decision support system for insect management in commercial grain elevators. J Stored Prod Res 43:375-383 (2007).

33 Hagstrum DW, Reed C and Kenkel P, Management of stored wheat insect pests in the USA. Integr Pest Manag Rev 4:127-142 (1999).

34 Rajendran S and Sriranjini V, Plant products as fumigants for stored-product insect control. J Stored Prod Res 44:126-135 (2008).

35 Phillips TW and Throne JE, Biorational approaches to managing stored-product insects. Annu Rev Entomol 55:375-397 (2010). 
36 Shirvani Farsani N, Zamani AA, Abbasi S and Kheradmand K, Effect of temperature and button mushroom varieties on life history of Lycoriella auripila (Diptera: Sciaridae). J Econ Entomol 106:115-123 (2013).

37 Grieshop MJ, Flinn PW and Nechols JR, Biological control of Indianmeal moth (Lepidoptera: Pyralidae) on finished stored products using egg and larval parasitoids. J Econ Entomol 99:1080-1084 (2006).

38 Faroni $\mathrm{L}$ and García-Mari $\mathrm{F}$, Influencia de la temperatura sobre los parámetros biológicos de Rhyzopertha dominica (F.). Bol San Veg Plagas 18:455-467 (1992).

39 Srivastava S, Mishra G and Mishra HN, FTNIR-a robust diagnostic tool for the rapid detection of Rhyzopertha dominica and Sitophilus oryzae infestation and quality changes in stored rice grains. Food Bioprocess Technol 11:785-796 (2018).

40 Bera A, Sinha SN, Singhal NC, Pal RK and Srivastava C, Studies on carbon dioxide as wheat seed protectant against storage insects and its effect on seed quality stored under ambient conditions. Seed Sci Technol 32:159-169 (2004)

41 Kramer KJ, Hendricks LH, Wojciak JH and Fylers J, Evaluation of fenoxycarb, bacillus thuringiensis, and malathion as grain protectants in small bins. J Econ Entomol 78:632-636 (1985).

42 Fatma F, Verma S, Kamal A and Srivastava A, Phytotoxicity of pesticides mancozeb and chlorpyrifos: correlation with the antioxidative defence system in Allium cepa. Physiol Mol Biol Plants 24:115-123 (2018).

43 Shakir SK, Kanwal M, Murad W, Rehman Z u, Rehman S u, Daud MK et al., Effect of some commonly used pesticides on seed germination, biomass production and photosynthetic pigments in tomato (Lycopersicon esculentum). Ecotoxicology 25:329-341 (2016).

44 Liu TF, Wang T, Sun C and Wang YM, Single and joint toxicity of cypermethrin and copper on Chinese cabbage (Pakchoi) seeds. J Hazard Mater 163:344-348 (2009). 